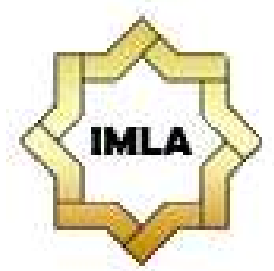

Al-Ta'rib

Jurnal Ilmiah Program Studi Pendidikan Bahasa Arab

IAIN Palangka Raya

Vol. 9, No. 2, December 2021, 155-172

p-ISSN 2354-5887 | e-ISSN 2655-5867

DOI: https://doi.org/10.23971/altarib.v9i2.3264

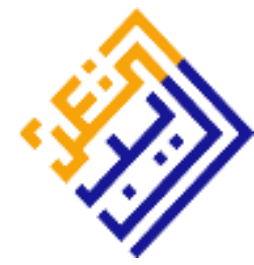

\title{
DEVELOPING AN INTERNATIONAL STANDARDIZED ARABIC LANGUAGE EDUCATION CURRICULUM: INTRODUCING A CONCEPTION-FOCUSED DESIGN AND OUTCOME
}

\author{
Yayan Nurbayan ${ }^{1}$, Sofyan Sauri ${ }^{2}$, Anwar Sanusi ${ }^{3}$ \\ 1,2,3 Universitas Pendidikan Indonesia, Indonesia \\ E-mail: yayannurbayan@upi.edu
}

\begin{abstract}
This research aimed to explore the concept of developing an international standard Arabic curriculum in universities. This curriculum development concept focused on curriculum design and graduate profiles. This study used a library research approach. The data analysis technique used the interactive data analysis model proposed by Miles et al. including data collection, data reduction, data display, and concluding. The study's results showed that the development of an international standard curriculum viewed consisted of 10 steps, namely research and collection, planning, developing initial products, conducting preliminary tests in the field, revising products, conducting field tests, revising operational products, conducting operational testing in the field, final product revision, and deployment and implementation. Meanwhile, the profile of Arabic education program graduates formulated consisted of three aspects: graduates with competence as teachers, employability skills, and 21st-century skills. Based on the results of this study, it is expected to bring enlightenment and academic horizons to education providers in higher education in developing an international standard Arabic curriculum.
\end{abstract}

Keywords: curriculum design, employability skills, graduate profiles, industry 4.0, 21st-century skills.

Abstrak
Penelitian ini bertujuan untuk membahas konsep pengembangan kurikulum
bahasa Arab berstandar internasional di perguruan tinggi. Fokus konsep
pengembangan kurikulum dalam hal ini adalah desain kurikum dan profil lulusan.
Penelitian ini menggunakan pendekatan studi pustaka. Teknik analisis data yang
digunakan adalah model analisis data interaktif yang dikembangkan oleh Miles dkk
yaitu: pengumpulan data, reduksi data, penjelasan data, dan penarikan
kesimpulan. Hasil penelitian menunjukkan bahwa dalam mengembangkan
kurikulum bahasa Arab berstandar internasional dilakukan 10 langkah sebagai
berikut: penelitian dan pengumpulan, perencanaan, mengembangkan produk awal,
melakukan uji pendahuluan di lapangan, melakukan revisi produk, melakukan uji
di lapangan, revisi produk operasional, melakukan uji operasional di lapangan,
revisi produk akhir, serta penyebaran dan implementasi. Sedangkan profil lulusan


pendidikan bahasa Arab yang dirumuskan terdiri dari tiga aspek, yaitu lulusan yang memiliki kompetensi sebagai guru, employability skills, dan keterampilan abad 21. Dari hasil penelitian ini diharapkan menghadirkan pencerahan dan cakrawala akademik bagi penyelenggara pendidikan di perguruan tinggi dalam mengembangkan kurikulum bahasa Arab berstandar internasional.

Kata kunci: desain kurikulum, internasional, konsep, profil lulusan

\section{INTRODUCTION}

In the industrial revolution 4.0 era today, the world of education, including universities, is faced with four phenomena, namely volatile, uncertain, complex, and ambiguous (Postangbam, 2017). Very dynamic (volatile) turmoil, sites that are sometimes uncertain, multi-problem and related to various aspects of life (complex), and future situations that are difficult to predict (ambiguous) greatly affect various orders of life, including the world of education. Higher education institutions as institutions that prepare Human Resources (HR) for various needs of the community are required to answer these challenges.

Other challenges that the world of education must face in the industrial era 4.0 bring new challenges and have a negative impact on life. These effects include disruptive phenomena. The influence of information technology developments that are so massive has uprooted various orders of human life, which ultimately has an impact on economic, social, political, educational, and cultural aspects. Another negative impact of this era was a cultural shock. A new culture as a result of the rapid development of technological advances makes humans shocked and unprepared to deal with it. In addition, there is also a lot of unemployment due to the use of robots and technological devices that can replace humans (Istyanto et al., 2019).

Higher education is expected to be able to prepare quality HR, competitive, and in accordance with the expectations of the community. All the things needed to realize these expectations, both regarding HR, facilities, and learning devices, need to be prepared as well as possible. In Government Regulation No. 12 of 2012 on Higher Education Article 18 paragraphs 1 and 2, it is explained that: (1) The undergraduate program is an academic education intended for graduates of secondary education or equivalent to be able to practice knowledge and technology through scientific reasoning; (2) The undergraduate program as referred to in paragraph (1) prepares students to become intellectuals or cultured scientists, able to enter or create jobs, and able to develop themselves into professionals.

The opportunities of graduates to acquire the world of work now are increasingly tight and competitive. Therefore, it is imperative that the learning method, facilities, and the development of outstanding qualities for each graduate be improved.

Graduates with expertise and competency mastery rely heavily on the quality of the human capital that manages them. The workplace environment is changing quickly in the era of the knowledge-based economy. This situation gives must challenges in the world of education and should become able to generate graduates with skills relevant to the demands of the workplace. The greatest 
difficulty in today's world of education is to create graduates with a comprehensive set of academic, technical, and employable abilities (Bennet, 2006).

Espoto \& Meagher research (2007) emphasizes that employability skills are an essential problem and a concern of the workforce in recent years. To maintain the growth of a knowledge-based economy, education that is focused on the requirements and expectations of the workplace by mastery of technical ability and employability is required. In addition, Cassidy (2006) and Yorke (2006) assert that employability skills are part of non-technical skills that are transferable into various work fields, needed to enter the workforce, to stay in the job, and to develop a career in the workplace, or for career development in a new workplace.

In connection with graduates of the Ministry of Arabic Language Education, it appears in the presentation of the 2018 Curriculum that graduates are expected to have competence in planning, implementing, and evaluating Arabic language learning, teaching Islamic Religious Education, translators, and hajj and Umrah guides (UPI Curriculum, 2018).

In the face of such situations, the Arabic Language Education Program must develop a curriculum that can answer these challenges. According to the World Economic Forum in its report The Future of Job Report 2017 explained there are five competencies that must be possessed by humans in facing this century, namely: 1) complex problem solving, namely the ability to solve complex problems; 2) process skills, namely the ability to active listening, logical thinking, and monitoring themselves and others; 3) social skills, namely the ability to coordinate, negotiate, persuasion, emotional intelligent with others; 4) system skills, namely the ability to make judgments and cost-benefit decisions about the system implemented; 5) cognitive abilities, namely flexibility, creativity, logical reasoning, and problem sensitivity (Schwab, 2018).

In producing graduates as described above, various components of the Arabic language education department in college must be developed to support the realization of the profiles. Various criteria connected to institution growth, such as mission vision implementation, governance efficiency and effectiveness, HR quality improvement, students feedback improvement, curriculum development, and implementation optimization, and extending collaboration networks, as well as increasing the linkage of lecturer research with the improvement of graduate services and quality.

Therefore, in this study, this researcher will examine related to the development of international standard Arabic language with a focus on the aspects of curriculum design that must be used and the expected graduate competency profile. In addition, the study of international standard Arabic curriculum in universities has not been found. Thus, researchers hope that the results of this study bring enlightenment and academic horizons to the organizers of education in universities in developing an international standard Arabic curriculum.

\section{METHOD}

This study was a descriptive research analysis that provided an overview of a symptom or phenomenon. This research used a library research approach, with data sources from books and articles related to the design of the international 
standard Arabic curriculum and the profile of qualified, competitive, and in accordance with community expectations.

The analysis techniques used interactive data analysis models. This was done through data collection, data reduction, data explanation, and conclusion withdrawal. This analytical technique is applied to a comprehensive overview of the concept of instituting an international standard Arabic curriculum in universities. More clearly, this analysis technique used an interactive data analysis model developed by Miles et al. (2014), namely: data collection, data reduction, data explanation, and conclusion withdrawal. These steps could be described as follows, the selection process, focused on simplification, abstraction, and explanation between aspects comprehensively and inferring.

\section{RESULT AND DISCUSSION}

\section{International Standard Curriculum Development}

Since the enactment of Law No. 20 of 2003 on The National Education System and PP Number 19 of 2005 on National Standards of Education, the Government of Indonesia has developed an international standard curriculum however in the development of the curriculum has not been as expected. The curriculum used should be a curriculum that is prepared and implemented by each educational unit on the curriculum of one of the member countries of the Organization for Economic Co-operation and Development (OECD) and other developed countries that have certain advantages in the field of education. According to the results of Widyastono research (2010), there are two things that can be implemented, namely: 1) Adaptation, which involves adjusting specific components that are already present in Content Standards (CS) and Graduate Competency Standards (GCS) with reference to the curriculum of one of the OECD member countries and other developed countries, and 2) Adoption, namely the adding of components to SI that does not currently exist in CS and GCS with reference to the curriculum of one of the OECD member countries and other developed countries. Thus, graduates can have a certificate (diploma) from Indonesia, one of the OECD member countries, and other developed countries.

1. Curriculum Adaptation

The term curriculum adaptation refers to the modification of specific components already included in the CS and GCS by referring to the standard of content and standards of competence of graduates (or other similar terms) one of the schools in OECD member countries and other developed countries that has specific educational advantages that have been established as "sister schools".

2. Curriculum adoption

Curriculum adoption is the addition of certain elements that are not yet in the CS and GCS by referring to the CS and GCS as one of the schools in OECD member countries and other developed countries that has specific educational advantages that have been established as "sister schools."

Adoption is carried out after going through the mapping process between the Content Standard and Standard of Graduate Competence. 


\section{International Standard Arabic Curriculum Design}

Curriculum design is a curriculum procedure that begins with planning and verification, implementation, and assessment. According to the findings of a study on the Design of Arabic Curriculum in Indonesia, the curriculum in Indonesia has changed throughout time. Arabic in ancient times can only be learned in boarding school, but the development of the Arabic language can also be learned in Islamic schools or madrassas (Utami, 2020). The objective of the design is for learners to be able to study Arabic correctly.

The conception and arrangement of various sections of the curriculum are some of the most significant aspects of it. Curriculum design is connected to horizontal and vertical structure in curriculum organization. Horizontal organization, often known as horizontal coverage or integration, is the process of arranging curricular components, while vertical organization is a sequence whose attention lies in the correlation between the components of the curriculum. Curriculum developers have constructed the curriculum according to the following categorization basics: 1) Subject-centred design, 2) Learner-centred design, namely learning-centered design, 3) Problem-centred design. Each of those ideas is turned into a curriculum design, which includes the key components of the curriculum, such as objectives, contents, learning experiences, and assessment, which are in accordance with the core of each design model (Ansyar, 2015).

In connection with that, the development of an international standard curriculum in universities is designed in the following steps:

1) information collecting.

The information collected includes: a) teacher competence, employability skills attributes that are essential for working in companies/industries, and 21st-century skills, b) contributions from curricular (academic), intracurricular, and extracurricular programs in developing student employability skills, as well as c) information about existing and utilized learning models. The collection of data and information uses a quantitative descriptive approach, qualitative descriptive, and focus group discussion (FGD). Some of these activities are carried out in the first year of research.

2) Planning

Activities at this stage include a) preparing the product specifications of employability skills; b) planning the setting or situation of the defense; c) establishing the learning component.

3) Develop the initial product

The next step is to develop the initial product. At this stage, they were developed in the form of learning programs following learning tools. Learning tools accompanying employability skills learning models include a) guidelines for lecturers, b) study contracts, and c) evaluation devices.

4) Conduct preliminary tests in the field

After the initial product is developed, then the next step is a preliminary test. Preliminary tests are intended to perfect the initial product or learning model already created. This preliminary test involves lecturers as well as learning experts. 
5) Revise the product

After a preliminary test, there will be deficiencies and inputs for improvement. The next step is product revision. Product revision was based on the conclusion of the data analysis results obtained from preliminary tests.

6) Conduct tests in the field

At this stage, conduct trials in the setting of learning in the classroom (theory) and learning in the laboratory (practice). In this trial, one class was selected for each major.

7) Revision of operational products Improvement of operational products is carried out based on the field test stage data analysis results.

8) Conduct operational tests in the field

This stage is the second trial, involving all parallel classes in one class in each major.

9) Final product revision

The ninth phase is the last revision, based on the data analysis results at the operational product trial stage in the field.

10) Deployment and implementation

The step at this stage is to disseminate the final product that has been tested in the field, especially to stakeholders, policymakers, and education practitioners.

Competency Profile of International Standard Arabic Language Education Graduates

As a product curriculum, the competence profile of graduates becomes one of the benchmarks of success and like the Arabic curriculum in universities. Therefore, the formulation of the profile of graduates of international standard Arabic language education is an inevitability. This is done as an effort to achieve the competence of qualified graduates and be able to face the challenges and demands of the times. Explicitly, the profile of Arabic in the industrial revolution era as 4.0 must have three aspects consisting of 1) teacher competence, 2) Employability skills, and 3) 21st Century skills (Sauri et al., 2021). This is in the picture as follows: 


\section{Picture 1. Arabic Education Graduate Profile}

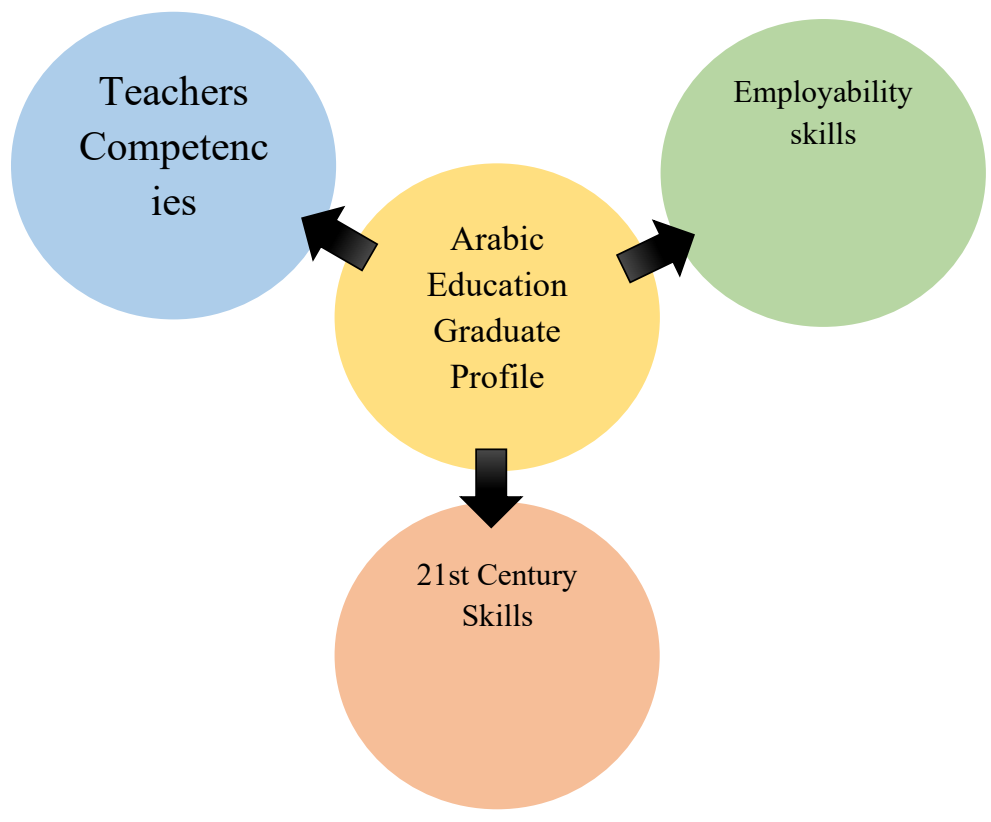

\section{Teachers Competencies}

Teachers Competencies are the result of a combination of education, training, and experience. Ability or competence is an attribute inherent in a person (Novauli, 2015). According to Daharti et al. (2013), competence may also be described as the understanding of fundamental skills and ideas that are represented in one's thinking and behaving habits. In connection with this, according to Koeppen et al. quoted by Herppich et al. (2017) that competence is also usually understood as the ability to think that is relevant to mastering real life.

Thus, teacher competence is a set of personal, scientific, technical, social, and spiritual qualities that together create up the quality competence of the teaching profession, which encompasses content mastery, student comprehension, educational achievement, and personal and professional growth. According to the explanations of government regulation number 19 of 2005 regarding national education standards, the government has defined four categories of teacher skills, including pedagogic, personality, social, and professional competencies (Musfah, 2011).

First, the issue of pedagogic competence is related to the ability to understand students in-depth and the implementation of educational learning (Ramayulis, 2013). Therefore, the pedagogic competence of a teacher is characterized by his ability to carry out a quality process of learning, as well as attitudes and actions that can be used as role models.

According to Mappanganro (2010) pedagogic competence consists of several things, namely: 1) Mastery of learning principles, 2) Consolidating understanding of the functions and objectives of education, 3) Strengthening 
understanding of the structure and content of the curriculum, and 4) Mastering the preparation of lesson plans.

Furthermore, Sagala (2011) explains that pedagogic competence is the ability to manage students, among others,

1) teachers understand the diversity of students so that learning service strategies can be designed according to the uniqueness of each student.

2) Teachers can develop a syllabus curriculum both in the form of documents and implementation in the form of learning experiences.

3) Teachers can create learning plans and methods that are based on competence requirements and fundamental skills.

4) Teachers are capable of conducting educational learning in an environment that is innovative, creative, and enjoyable.

5) Able to assess learning outcomes in accordance with established processes and standards.

6) Able to develop student's abilities and interests through intracurricular and extracurricular activities in order to maximize their potential.

Second, personality competence. Rochman \& Gunawan (2011) asserted that personality competence is a skill that indicates a solid, stable, mature, smart, and authoritative personality, as well as being a role model for learners. The teacher's personal abilities include 1) the appearance of a positive attitude towards his overall duties as a teacher, and towards the overall educational situation and its elements, 2) understanding, appreciation and appearance of values that should be embraced by a teacher, 3 ) personality, values, an attitude of life is displayed in an effort to make himself a role model and role model for his students.

Furthermore, viewed from the psychological aspect, personality competencies include personality abilities, identity as a teacher becomes a role model for students. This competence always illustrates the principle that a teacher is a person who should be respected and imitated (Janawi, 2011; Huda, 2017; Sauri et al., 2021). In other words, the teacher becomes a role model for students, or the teacher becomes a basic resource for students.

Third, Teachers' social competency refers to their capacity to communicate and engage successfully with learners, fellow educators, education staff, parents/guardians of students, and the community (Mulyasa, 2009). As a result, teachers must have sufficient social competency, particularly in regard to education, which includes not only teaching in schools and madrasas and moreover education that occurs and takes place in society.

From the definition above, it can be concluded that teacher social competence is a teacher's social ability which includes the ability to adapt to the demands of work and the surrounding environment when carrying out his duties as a teacher and social communication skills both with students, fellow teachers, school principals, administrative staff, even with members of the public.

Fourth, professional competence. Professional competence is the ability to master learning material broadly and deeply that allows guiding students to meet the competency standards set out in the National Education Standards (Prayitno, 2020). Professional competence is also the most core competency 
that must be possessed by all teachers, especially Arabic teachers, as shown in the picture as follows.

\section{Picture 2}

According to Suharsaputra (2013) about the Teacher Competency Model (adapted from Law No. 14/2005).

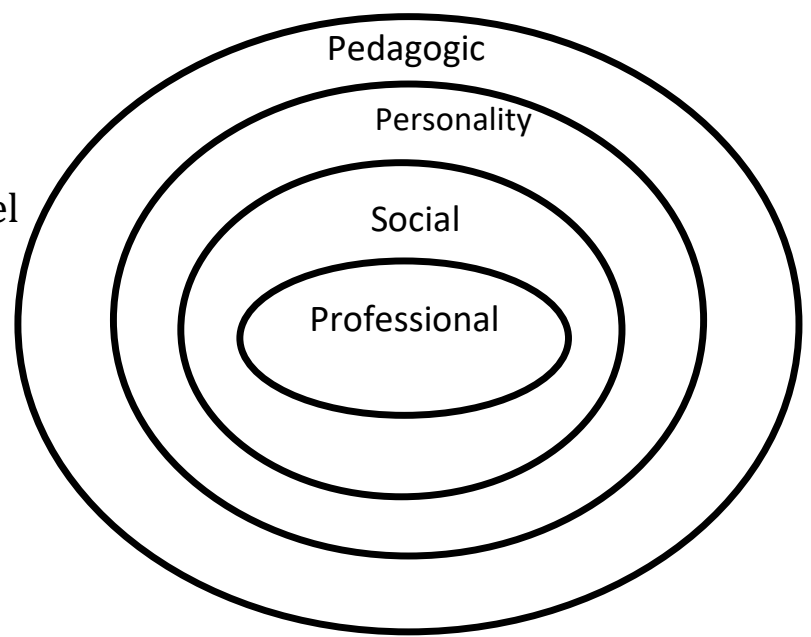

From some of these understandings, it can be understood that the professional competence of teachers refers to the ability of a teacher to carry out learning well. This is in line with the research results of Sanusi et al. (2020) that teacher competencies include professional competence related to the teacher's ability to plan, implement, and evaluate learning.

\section{Employability skills}

In addition to the previously described competencies, Arabic language education graduates should also have academic skills, technical skills, and employability skills.

Observing stakeholders' development and demand change nowadays, the characteristic development of employability skills is very important for students. There are various definitions of employability skills. According to Overttom (2000), Employability skills are transferrable core skill sets that reflect key functional and facilitating knowledge, skills, and attitudes necessary in the twenty-first-century workplace. They are required for professional success at all levels of job and education. Some phrases used interchangeably to define the employability abilities necessary in today's work environment include core skills, key skills, transferable skills, general skills, non-technical skills, soft skills, and important skills. (NCVER, 2003).

Based on these definitions, it can be summarized that employability skills are a number of non-technical competencies relevant to the work world's needs nowadays and can be transferred into various fields of work. This skill is very important for entering the work world, surviving and developing a career at work, or developing a career in a new workplace.

According to CBI/NUS (2011), employability skills relate to a variety of general abilities such as self-management, teamwork, business and customer awareness, decision making, communications, numeracy application, and information systems application. Employability, according to UNESCO Regional Bangkok (2012), refers to the characteristics and skills that enable job seekers to find work, such as (1) communication skills, (2) logical, analytical, and 
problem-solving skills, (3) personality, esteem, and integrity, (4) flexibility and adaptability, (5) advancement and creativity, and (6) team spirit.

BCA/ACCI proposes an employability skills framework consisting of eight main skill groups and some personal attributes. The eight main skill groups include (1) communication; (2) teamwork; (3) problem solving; (4) initiatives and enterprises; (5) planning and organizing; (6) self-management; (7) learning; and (8) technology. Yorke \& Knight (2006) identify 39 employability attributes that are considered important to be used as starting points in analyzing educational programs and curricula. These attributes are grouped into three main categories: personal qualities, core skills, and process skills. Maxwell et al. (2009) identify ten main skills, namely: (1) communication skills, (2) decision-making skills, (3) independent working skills, (4) information retrieval skills, (5) leadership skills, (6) numerical skills, (7) personal learning and development skills, (8) problem-solving skills, (9) strategic skills, and (10) team working skills. Based on a review of various literature, Marchioro et al. (2011) summarize the attributes into four main skill groups, namely: team skills, personal attributes, real-world skills, and academic skills.

The research result by Robinson (2006) shows ten attributes of employability skills that are considered important according to alumni perceptions, including (1) problem-solving ability, (2) ability to work independently, (3) ability to work well in stressful situations, (4) the ability to maintain a positive attitude, (5) the ability to listen with understanding, (6) the ability to identify problems, (7) the ability to work well with colleagues, (8) the ability to prioritize, (9) the ability to manage time effectively, and (10) the ability to relate well with leaders.

Research by Ogbeide (2006) shows the employability skills attributes that require a high level of competence according to students' perceptions for the benefit of a career in the hospitality industry include: the ability to work independently, provide direction and guidance to others, gain new knowledge from experience every day, maintain a positive attitude, conducting supervising to others' work, coordinate work with colleagues, maintain good relations with subordinates, relate well to supervisors, demonstrate optimal performances, delegate work with subordinates, work well with colleagues, and be able to make priorities.

Thus, the employability skills need to be possessed by Arabic language education graduates. Because of this, they will be able to work effectively and efficiently to have a positive impact on institution progress. In addition, the development of information and communication technology today demands the competence level of graduates who are able to quickly anticipate any changes and developments, so that the demands for work skills continue to grow as well. So work skills must continue to be developed along with these changes and developments.

\section{21st Century Skills}

21st-century skills are a set of skills that should be possessed in an integrated by individuals, which consist of problem-solving skills, communication skills, working in teams, using information and communication technology, innovating, and thinking creatively on contextual themes or issues 
effectively and efficient (Trilling \& Fadel, 2009). Therefore, in the education domain, Arabic Language Education graduates are required to have competent teaching skills to learn and engage so that learning objectives are achieved.

Furthermore, teachers play a critical role in assisting students in reaching their full potential and achieving their life objectives. Without the teacher's assistance, students' interests, skills, capabilities, and potential will not be able to grow to their full potential. Teachers are expected to pay attention to students optimally. That is why, besides paying attention to the students in groups, the teachers are also expected to pay attention to the students individually.

Therefore, education must be organized in such a manner that students can naturally and artistically develop their potential in an environment of freedom, unity, and responsibility.

Learning design can be started from the performance aspect or from the informational aspect. If it starts from the behavioral approach, the designer must first determine what students can do and what they should do. If starting from the informational approach, the designer must determine knowledge or information that is available and desired by students. Information is an explanation that exists and is outside of a person, while knowledge is an explanation that has been owned or saved in oneself (Hamalik, 2014).

Teachers in conducting learning require professional readiness so that learning objectives can be achieved optimally. One form of teacher readiness before conducting classroom learning is to develop relevant learning designs with the times and needs of the students. The learning design that must be prepared includes three main things: learning objectives, core learning materials, and learning evaluation. Teachers in setting learning objectives based on the curriculum by developing core competencies and basic competencies, and it adapted to the students' social environment in everyday life.

Apart from this, 21st-century skills are also conveyed in different ways, but emphasize these 21st-century skills on aspects: complex and higher-order thinking (creativity, metacognition), communication, collaboration, and more demanding learning and teaching than memorizing. In line with that, Roekel (2011) explains the skills that must be mastered by students, namely through the 4 C's, as follows:

\section{Critical Thinking and Problem Solving}

Critical thinking, according to AMSC (Mahanal, 2009) is described as an orderly self-directed mind that shows intellectual skills and metacognitive abilities. In this skill, the students are required to demonstrate the following abilities: a) Focusing on problems (identifying and solving the problems), b) Analyzing arguments, c) Asking and answering questions, d) Determining credible sources, e) Determining and making observations, f) Conducting deductions, g) Conducting induction, h) Determining and making evaluations, i) Giving definition, j) Identifying assumptions, k) deciding and doing, l) Interacting with others, and metacognition.

Critical thinking ability is one of basic capital or intellectual capital that is very important for everyone and is a fundamental part of human 
maturity. There is a significant relationship between critical thinking and learning outcomes. Critical thinking contributes to successful learning at the primary, secondary, and tertiary education levels. Critical thinking also contributes to career success.

\section{Communication}

Communication is key to success in anything. If someone's communication is good, diction using is good, easy to understand, the message is short, clear, and following the expected outcome, it can convince the recipient or speaking partner. Good communication competence will influence the information recipient to follow or at least not to reject the information.

This competency is important because in any business, in any profession, communication is a very vital part that cannot be separated from social dynamics. Communication is the process of delivering information to other people either directly face to face or by cell phone, orally, or so on. Because verbal communication is very important, it needs to be cultivated from an early age. Written communication is also needed because this is the skill of how to convey messages in writing with a choice of sentences, words, grammar, and other rules so that it is easily understood by others or readers (Willis, 1981).

\section{Collaboration}

In various occupations, companies often carry out cooperations, whether by forming a consortium to undertake a very big project or simply by developing cooperation by helping each other complete a job or by collaborating in developing business between producers, distributors, and marketing.

Collaboration is none other but cooperation by exchanging information, developing various options for joint activities and work, sharing resources, increasing the capacity of each organization to achieve common goals, and being developed through networking, coordination, and cooperation between institutions and organizations.

According to Sauri et al. (2021), Collaboration skills can be characterized by the following indicators:

1) Demonstrating the ability to work together in groups effectively and with mutual respect.

2) Personal flexibility, willingness to help each other, compromise to achieve common goals.

3) Work productively with others, take responsibility, and contribute to work.

\section{Creativity and Innovation}

Some people assume that creativity is innate from birth. Thus, there are only a few creative people in this world because they think creativity is natural potential. However, education experts do not believe this, so until today, it is still being designed to prepare creative nation's children through the educational process. Creativity itself means the ability to create an idea or a new concept to solve a problem, or on the other hand, the ability to 
create a new prototype in creating a new product to be produced (Rosyadah, 2017).

The definition above implies four criteria that a person has to be called a creative person. First is the ability to think divergently, which can provide different solutions from others about a problem. Second, have qualified knowledge and accompanied by previous experience. Third, it has the ability to communicate so that we can exchange information with colleagues or businesses. Fourth, have the capacity to think critically and have good analytical skills.

Creativity is the ability to create something, apply a new form, produce imaginative skills, or make something that already exists into something new (Greenstein, 2012). Meanwhile (Roekel, 2011) divides creativity into two parts, namely:

1) Creative thinking has several indicators, as follows:

a) Able to use various ways to generate ideas, for example, through brainstorming (discussion)

b) Creating new ideas and adding ideas

c) Elaborating, refining, analyzing, and evaluating original ideas to enhance and maximize creative endeavors.

2) Creative work, including the following things:

a) Developing, implementing, and communicating new ideas to others effectively

b) Being open and responsive to new and diverse perspectives

c) Receiving group input and feedback

d) Demonstrating creative originality in work and understanding limits in adopting new ideas

e) Seeing failure as an opportunity to learn

f) Understand that creativity and innovation are part of a long chain of processes.

Thus, it is no longer disputed that creativity is formed and not innate. Creativity is closely related to several other critical thinking and problem solving, communication, and collaboration skills. Creativity always goes hand in hand with innovation because both are almost the same, that creativity always demands new thoughts, new ideas to solve problems. In the creative thinking process, a phase is passed to create a new formulation, and there is a process of implementing the formulation so that it can be used in problem-solving.

\section{CONCLUSION}

Based on the explanation above, it could be concluded that the development of an international standard curriculum viewed from the aspect of curriculum design consisted of 10 steps, including research and collection, planning, developing initial products, conducting preliminary tests in the field, revising products, conducting field tests, operational product revision, conducting the operational test in the field, final product revision, and deployment and implementation. Then, the graduate profiles of the Arabic education program formulated consisted of three aspects: graduates who have competence as teachers, including pedagogic competence, personality competence, social 
competence, and professional competence. In addition, graduates of the Arabic education program must have employability skills and 21st-century skills. The development process was comprehensive and carried out in stages, and continued to achieve educational goals. The more advanced the era, the better the curriculum of the Arabic education program must be developed. Therefore, as lecturers, they should teach, especially Arabic, using the latest curriculum along with the development of the era and be more creative in teaching so that the students are more enthusiastic in following lectures.

\section{REFERENCE}

Ansyar, Mohamad. (2015). Kurikulum Hakikat, Fondasi, Desain dan Pengembangan. Jakarta: PT Fajar Interpratama Mandiri.

BCA/ACCI. (2002). Employability skills for the future. A Report by the Australian Chamber of Commerce and Industry (ACCI) and the Business Council of Australia (BCA) for the Department of Education, Science and Training, Canberra.

Bennett, T. M. (2006). Defining the importance of employability skills in career/technical education. Dissertation (unpublished). Auburn, Alabama: The Graduate Faculty of Auburn University.

Cassidy, S. (2006). Developing employability skills: Peer assessment in higher education. Education + training, 48(7): 508-517.

Confederation of British Industry and National Union of Students (CB/NUS). (2011). Working towards your future: Making the most of your time in higher education. Accessed on March 20, 2021 from http://www.cbi.org.uk/pdf/cbinus-employability-report.pdf.

Daharti, dkk. (2013). Strategi Peningkatan Kompetensi Guru dengan Pendekatan Analysis Hierarchy Process. JEJAK journal of economic and Policy, 6(1), 8192.

Depdiknas. (2003). Undang-undang RI No.20 tahun 2003 tentang sistem pendidikan nasional. Jakarta: Depdiknas.

Depdiknas. (2005). Peraturan Pemerintah Republik Indonesia Nomor 19 tahun 2005 tentang Standar Nasional pendidikan. Jakarta: Depdiknas.

Esposto, A., \& Meagher, G.A. (2007). The future demand for employability skills and the implications for the VET system. Accessed on July 8th, 2021 from http://www.avetra.org.au/publications/12-Esposto.pdf

Greenstein, L. (2012). Assesing 21 st Century Skill A Guide to Evaluating Mastery And Authentic Learning. Corwin a Sage Company.

Hamalik, O. (2014). Teacher Education Based on Competency Approach. Jakarta: PT Bumi Aksara.

Herppich, Stephanie., Praetorius, Anna-Katharina., Forster, Natalie., Frey, Inga Glogger., Karst, Karina., Leutner, Detlev., Behrmann, Lars., Bohmer, Matthias., Ufer, Stefan., Klug, Julia., Hetmanek, Andreas., Ohle, Annika., 
Bohmer, Ines., Karing, Constance., Kaiser, Johanna., Südkamp, Anna. (2018). Teachers' assessment competence: Integrating knowledge-, process, and product-oriented approaches into a competenceoriented conceptual model. Teaching and Teacher education. Vol. 76, 1-13. DOI: 10.1016/j.tate.2017.12.001

Huda, Mualimul. (2017). Kompetensi Kepribadian Guru dan Motivasi Belajar Siswa (Studi Korelasi pada Mata Pelajaran PAI). Jurnal Penelitian, 11(2), 237-266. http://dx.doi.org/10.21043/jupe.v11i2.3170

Istyanto, Noerma Puji., \& Nasrullah, Muhammad. (2019). Disruptif Teknologi EGovernment terhadap Pelayanan Publik Tradisional Masyarakat Surabaya di Era Industri 4.0. INTEGER: Journal if Information Technologi, 4(2), 1-11.

Janawi. (2011). Kompetensi Guru: Citra Guru Profesional, Cet. I. Bandung: Alfabeta.

Mahanal, S. (2009). Pengaruh Perangkat Pembelajaran Deteksi Kualitas Sungai Dengan Indikator Biologi Berbasis Proyek Terhadap Hasil Belajar Siswa SMA Di Kota Malang. Disertasi tidak diterbitkan. Program Pasca Sarjana (S3) Universitas Negeri Malang.

Mappanganro. (2010). Pemilikan Kompetensi Guru. Makassar: Alauddin Press.

Marchioro, G., Ryan, M.M., \& Cripps, H. (2011). Student enfranchisement in business undergraduate studies. Asia-Pacific Journal of Cooperative Education, 12(2): 103-110.

Maxwell, G., Scott, B., Macfarlane, D., \& Williamson, E. (2009). Employers as stakeholders in postgraduate employability skills development. The International Journal of Management Education, 8(2), 1-22. DOI: 10.3794 /ijme.82.267.

Miles, M. B., Huberman, M., \& Saldana, J. (2014). Qualitative data analysis. London: SAGE Publication Inc.

Mulyasa. E. (2009). Standar Kompetensi dan Sertifikasi Guru, Cet. IV. Bandung: Remaja Rosdakarya.

Musfah, Jejen. (2011). Peningkatan Kompetensi Guru: Melalui Pelatihan dan Sumber Belajar Teori dan Praktik, Cet. I. Jakarta: Prenada Media Grup.

NCVER. (2003). Defining generic skills: At a glance. Adelaide, Australia: National Centre for Vocational Education Research (NCVER).

Novauli, M Feralys. (2015). Kompetensi Guru dalam Peningkatan Prestasi Belajar pada SMP Negeri dalam Kota Banda Aceh. Jurnal Administrasi Pendidikan, 3(1), 45-67.

Ogbeide, G.C.A. (2006). Employability skills and students' self-perceived competence for careers in the hospitality industry. Doctoral Dissertation (unpublished). Columbia: University of Missouri.

Overtoom, C. (2000). Employability skills: An update. ERIC Digest No. 220. Columbus, Ohio: ERIC Clearinghouse on Adult, Career, and Vocational 
Education. Accessed on August 20, 2021 from http://www.ericdigests.org/2001-2/skills.htm.

Peraturan Pemerintah Nomor 12 Tahun 2012 tentang Pendidikan Tinggi.

Postangbam, Chandibai. (2017). Adaptive Performance in VUCA Era- Where is Research going. International Journal of Management, 8(6), 99-108.

Prayitno, Agus. (2020). Kompetensi Profesional Guru MA An-Nur Setupatok Kabupaten Cirebon. Jurnal Manajemen Pendidikan, 1(1), 19-25, 14-19.

Ramayulis. (2013). Profesi dan Etika Keguruan. Cet. II. Jakarta: Kalam Mulia.

Robinson, J.S. (2006). Graduates' and employers' perceptions of entry-level employability skills needed by agricultural, food and natural resources graduates. Doctoral Dissertation (unpublished). Columbia: University of Missouri.

Rochman, C \& Gunawan, H. (2011). Pengembangan Kompetensi Kepribadian Guru; Menjadi Guru Yang Dicintai dan Diteladani Oleh Siswa, Cet. I. Bandung: Nuansa Cendekia.

Roekel, D. (2011). Preparing 21st Century Students for a Global Society: An Educator's Guide to The "Four Cs". NEA (National Education Association).

Roekel, D. (2011). Preparing 21st Century Students for a Global Society: An Educator's Guide to The "Four Cs". NEA (National Education Association).

Rosyadah, D. (2017). Madrasah dan Profesionalisme Gur. Jakarta: Kencana.

Sagala, S. (2011). Kemampuan Profesional Guru dan Tenaga Kependidikan. Cet. III. Bandung: Alfabeta.

Sanusi, A., Sauri, S., \& Nurbayan, Y. (2020). Non-native Arabic language teacher: Low teacher's professional competence low quality outcomes?. Arabiyât: Jurnal Pendidikan Bahasa Arab dan Kebahasaaraban, 7(1), 45-60. doi:10.15408/a.v7i1.12722

Sauri, Sofyan, Saepulloh., \& Sanusi, A. (2021). Guru Profesional Abad-21. Mustika Ilmu.

Schwab, Klaus. (2018). The Future of Jobs Report 2018. Geneva: World Economic Forum.

Suharsaputra, Uhar. (2013). Menjadi Guru Berkarakter. Bandung: PT Refika Aditama.

Trilling, B., \& Fadel, C. (2009). 21st Century Skills: Learning for Life in Our Times. Jossey-Bass.

UNESCO Bangkok. (2012). Graduate Employability in Asia (elektronik version). Accessed on March 21, 2021 from http://unesdoc.unesco.org/images/0021/002157/ 215706E.pdf

Universitas Pendidikan Indonesia. (2013). Kurikulum Universitas Pendidikan Indonesia Tahun 2013. Bandung: UPI Press. 
Utami, Rika Lutfiana. (2020). Desain Kurikulum Bahasa Arab di Indonesia. ElIbtikar, 9(1), 108-124. DOI: 10.24235/ibtikar.v9i1.6235.

Widyastono, Herry. (2010). Pengembangan Kurikulum Bertaraf Internasional. Jurnal Pendidikan dan Kebudayaan, 16(3), 265-274.

Willis, S. S. (1981). Problema Remaja dan Pemecahannya. Bandung: Angkasa.

Yorke, M., \& Knight, P.T. (2006). Embedding employability into the curriculum. United Kingdom: The Higher Education Academy.

Zuhal. (2008). Kekuatan daya saing Indonesia: Mempersiapkan masyarakat berbasis pengetahuan. Jakarta: Penerbit Buku Kompas.

\section{COPYRIGHT NOTICE}

Authors retain copyright and grant the journal right of first publication with the work simultaneously licensed under a Creative Commons Attribution 4.0 International License that allows others to share the work with an acknowledgement of the work's authorship and initial publication in this journal. 
HALAMAN INI SENGAJA DIKOSONGKAN

Jurnal Ilmiah Program Studi Pendidikan Bahasa Arab IAIN Palangka Raya Vol. 9, No. 2 /155-172 Al-Ta'rib | p-ISSN 2354-5887 | e-ISSN 2655-5867 